\title{
Early verb development of two finnish-speaking children: a preliminary approach to miniparadigms
}

\author{
Klaus Laalo \\ Tampere \\ skklla@uta.fi
}

\section{Introduction}

This paper is a preliminary overview of the early acquisition of verb inflection in Finnish. The analysis of the first verb forms concentrates on two children, but background material from other children is also used. The analysis of the first miniparadigms concentrates on one girl (Tuulikki).

\section{Verb inflection in spoken Finnish}

\subsection{Verbal categories}

The Finnish verb categories which emerge relatively early in the speech of children are:

prod. synthetic

PERSON (+ VOICE)

- ACTIVE (unmarked): 3 persons in singular and in plural (total 6); $3^{\text {rd }}$ SG is the most unmarked

- "PASSIVE" $=$ the indefinite $4^{\text {th }}$ person without person distinctions (the forms of this socalled personal passive are also used in spoken Finnish - and in child language - in the function of the $1^{\text {st }}$ person PL of active)

\section{TENSE}

- PRESENT (unmarked)

- PRETERITE (PAST): $i$-suffix in Standard Finnish, e.g. present nukkuu vs. preterite nukkui, present antaa vs. preterite antoi; in colloquial speech also shortening and change of the final stem vowel, e.g. present antaa vs. preterite anto, present nukkuu vs. preterite $n u k k u$; in spoken Finnish the $3^{\text {rd }}$ person SG of contracted verbs -si >-s (e.g. haukkasi > haukkas), and the $s$ originally belonging to the stem is now a tense marker

MOOD

- indicative (unmarked)

- imperative $2^{\text {nd }}$ person SG and PL + eventually $3^{\text {rd }}$ person

- conditional (isi-suffix); potential (ne-suffix)

INFINITIVES

- $1^{\text {st }}$ infinitive (TA-suffix)

- $3^{\text {rd }}$ infinitive ( $\mathrm{mA}$-suffix + case endings: illative $-\mathrm{Vn}$, inessive $-\mathrm{ss} \mathrm{A}$ etc.)

- eventually $2^{\text {nd }}$ infinitive (Te-suffix + case endings, either inessive - ss A or instructive $-n$ )

PARTICIPLES

- active and passive past participles (obligatory in analytic constructions)

- eventually present participles of some verbs

prod. analytic

NEGATION CONSTRUCTION: Finnish has a negation verb (stem e-, in imperative stem äl-). This verb is inflected and the main verb is in the negation form (which is identical with 
the $2^{\text {nd }}$ person SG imperative, e.g. minä en nuku 'I don't sleep', sinä et nuku 'you don't sleep', hän ei nuku 'he doesn't sleep', me emme nuku 'we don't sleep' etc.).

COMPOUND PAST ("perfect tense") = AUX olla 'to be' + the past participle of the main verb.

At first, children may use only some part of these constructions (e.g. Tuomas, Table A; 4a+b, $18 \mathrm{c})$.

All these verb categories are productive. The morphologically most simple forms, indicative present SG 3 and imperative SG 2, can be regarded as the basic forms of the verb (cf. Toivainen 1980: 44).

\subsection{Verb classes which Finnish-speaking children use relatively early}

1.2.1. verbs with only vowel stem that ends in a short vowel (e.g. istu-a 'to sit', sano-a 'to say'; the $A$ is the suffix of the infinitive); this is the most common and productive type of Finnish verbs

1.2.2. verbs with only vowel stem + the vowel stem ends in two vowels

a) one-syllabic verbs, e.g. syö- 'eat', juo- 'drink', vie- 'take away' (the past tense is in this verb class exceptional, e.g. syön 'I eat': söin 'I ate', and analogical formations are common in child language, e.g. syöin = simply syö $+\mathrm{i}+\mathrm{n})$; this class is unproductive

b) longer ones (the type mestaroi-) are acquired later; this class is weakly productive

1.2.3. contracted verbs: the vowel stem ends in two vowels, and there is also a consonant stem (e.g. kiipeää $\sim$ kiipee : kiivet $+k \ddot{a} \ddot{a}$ 'climb'); analogical forms are typical for early child language, e.g. kiipeää $\sim$ kiipee : kiipi instead of kiipesi (ex analogia lukee : luki or hakee : haki in the 1. type of verbs); this verb class is productive

1.2.4. other verbs with both a vowel and a consonant stem: the vowel stem ends in a short $e$ (e.g. tule- 'come' : tul+kaa, mene- 'go' : men+kää)

\subsection{Examples of the paradigms}

Present indicative forms of verbs belonging to the 1 . class in 1.2 above SG PL

1. person istu-n istu-mme $\sim$ istutaan (the latter one, "passive", is used in spoken Finnish)

2. person istu-t istu-tte

3. person istu-u istu-vat

Past tense (preterite) stem: istui- (istuin, istuit, istui etc. but in colloquial speech SG3 is istu)

Present indicative forms of verbs belonging to the 2. class:

SG PL

1. person vie-n vie-mme $\sim$ viedään (the latter one is the so-called "passive")

2. person vie-t vie-tte

3. person vie vie-vät

Past tense (preterite) stem: vei- (vein, veit, vei etc.); infinitive: viedä

Present indicative forms of verbs belonging to the 3. class:

SG PL

1. person hyppää-n hyppää-mme hypätään ("passive")

2. person hyppää-t hyppää-tte

3. person hyppää hyppää-vät

Past tense (preterite) stem: hyppäsi- (hyppäsin, hyppäsit, hyppäsi etc.); infinitive: hypätä 
Present indicative forms of verbs belonging to the 4. class:

SG PL

1. person tule-ntule-mme $\sim$ tullaan (this "passive" is based on the consonant stem)

2. person tule-t tule-tte

3. person tule-etule-vat

Past tense (preterite) stem: tuli- (tulin, tulit, tuli etc.); infinitive: tulla (consonant stem)

\section{Data description}

The study is mainly based on the corpora of two children, Tuulikki and Tuomas.

Tuulikki, girl, was born 28. 6. 1991; there is available diary data from the onset of speech and recordings from the age of 1;7 onwards. Until now, transcribed recordings are

$1 ; 7(60+30 \mathrm{~min}$, transcribed to a large extent) 199 utterances (child speech)

$1 ; 8$ (90 min, only partly transcribed) 225 utterances (child speech)

$1 ; 9$ (30 min, only partly transcribed)

$1 ; 10$ (30 min, only partly transcribed)

172 utterances (child speech)

$1 ; 11$ (60 min, transcription in progress)

68 utterances (child speech)

$2 ; 1$ (60 min, transcribed to a large extent) 136 utterances (child speech)

The transription process is continued during the winter 2000-2001 and will concentrate on the partly transcribed recordings in order to make them fully available in spring 2001.

Tuomas, boy, born 25. 5. 1997; there is diary data from the onset of speech and recordings from the age of $0 ; 9$. Until now, partly transcribed recordings are $1 ; 6(30 \mathrm{~min})$ and $1 ; 7(30$ $\min )$.

\section{Predecessors of verbs in predicative function}

Elements expressing actions, events and processes before adult-like verbs:

a) no replacement of verbs by fillers

b) no prefixes but e.g. pois 'away' (also in truncated form: po etc.) from the expression mene mennä(än) pois 'go away' is used much in the same way as the English verb particle away (cf. partially the German prefix weg)

Presumably, pois is favoured by small children because it is short and has only one form, whereas the verb is more demanding: it is inflected in different forms and it is longer.

c) objects, especially mass nouns in partitive instead of their governing verbs: vettä $\sim$ tett $\ddot{a}$ 'water' in the meaning 'give me some water [to drink]', pullaa $\sim$ puuroa $\sim$ puuvoo etc. in the meaning 'give me some buns/porridge [to eat]';

Also some illative forms: kotiin '[let's go] home' and syliin '[I want to come] into the lap' (morphologically kotiin $=$ koti 'home' + the illative suffix $-i n$, and syliin $=$ syli + the illat. suffix -in); cf. to the early illative forms of the $3^{\text {rd }}$ infinitive (e.g. syömään 'come to eat', consisting of the verb stem $s y \ddot{o}-$, the suffix of the $3^{\text {rd }}$ infinitive $-m A$ - and the illative suffix än).

d) early reduplicative expressions, attested from many Finnish children: anna-anna-anna-anna $\sim$ mam-mam-mam-mam nam-nam-nam-nam 'give (something to eat/drink, used often in combination with a pointing gesture)'; more idiosyncratic: Tuulikki's ihhaa ihhaa (< shortened from the nursery rhyme "ihhahhaa, ihhahhaa, hepo hirnahtaa", used when riding 
with a toy horse or - by the child - even when seeing a picture of a horse). The form anna is the $2^{\text {nd }}$ person imperative of the verb antaa 'to give', the other reduplicative expressions are built on onomatopoetics; both nam 'yum yum' and ihahaa (imitating the voice of the horse) can occur also alone, but mam is not an established interjection in (adult) Finnish.

e) onomatopoetic forms, both reduplicative (cf. point d above) and others, e.g. miau imitating the sound of the cat, surrur and prr imitating the sounds of different machines; these onomatopoetic words are iconic in the sense that they refer directly to their referents and simultaneously indexical in the sense that they refer specifically to the sound produced by their referents

\section{The first verbs and their forms of two Finnish children}

(Tuulikki, girl, and Tuomas, boy; the first 50+ verbs (diary data and recordings))

Also diary data is included because the very first verb forms have not been recorded. Already in the first recordings of Tuulikki $(1 ; 7)$ there are many verb forms; from the recordings of Tuomas, only 1;6 and 1;7 are (partly) transcribed. The first forms to emerge are imperative singular $2^{\text {nd }}$ and indicative singular $3^{\text {rd }}$. Some other form categories emerge rather early (passive, infinitives, negation verb, participles) but the $3^{\text {rd }}$ form to be used productively is the preterite (past tense) $3^{\text {rd }}$ person. In certain forms, the colloquial (shorter) variant is used instead of the standard variant (e.g. 20 tippu, 48 kuulu; cf. 1.a: PAST TENSE). Certain forms are shortened because of the strong trochaic tendency in Tuulikki's speech, e.g. 8 kävele- > käme.

TABLE A1: The first $50+$ verbs of Tuulikki $(\mathrm{F}=\mathrm{a}$ formulaic, frozen word-form) $[$ lemma $=($ strong $)$ vowel stem $]$

\begin{tabular}{|c|c|c|c|c|c|}
\hline AGE & NUMBER & LEMMA & ENGLISH & $\begin{array}{l}\text { first } \\
\text { occurrence }\end{array}$ & CATEGORY \\
\hline $0 ; 10$ & 1 & katso- & look & kato [ato] & imperat SG2 \\
\hline $1 ; 3$ & 2 & avaa- & open & avaa & imperat SG2 \\
\hline \multirow[t]{4}{*}{$1 ; 4$} & 3 & anta- & give & anna & imperat SG2 \\
\hline & 4 & hyppi- & jump & hyppii & indicat SG3 \\
\hline & 5 & vetä- & push & vetää & indicat SG3 \\
\hline & 6 & menc- & go & mennään & passive present \\
\hline \multirow[t]{15}{*}{$1 ; 5$} & 7 & istu- & sit & istuu [ittuu] & indicat SG 3 \\
\hline & 8 & kävele- & walk & kävelee [käme] & indical SG 3 \\
\hline & 9 & nukku- & sleep & nukkuu & indicat SG 3 \\
\hline & 10 & pane- & put & pane [mane] & imperat SG2 \\
\hline & 11 & otta- & take & ota & imperat SG2 \\
\hline & $11 b$ & olta- & take & oltaa & indicat SG3 \\
\hline & 13 & pakkaa- & pack & pakkaa & indicat SG3 ('is packing') \\
\hline & 14 & pese- & wash & pese & imperat SG2 \\
\hline & 15 & piirtääi & draw & piirtää [piittää] & indicat SG3 \\
\hline & 16 & pitä- & \multicolumn{2}{|c|}{ 'must' (modal)pitää } & indical SG3 \\
\hline & 17 & potki- & kick & potkii [pokkii] & indicat SG3 \\
\hline & 18 & pumpe & \multicolumn{2}{|c|}{ (playful gymnastics) } & (no suffix elements) \\
\hline & & \multicolumn{4}{|c|}{ ( $<$ motherese pumperoi; the form is shortened to the bare stem) } \\
\hline & 19 & tanssi- & dance & $\operatorname{tanssii}[\operatorname{ta}(a) s s i i]$ & indicat SG3 \\
\hline & 20 & lippu- & fall & tippui [tippu] & past indicat SG3 \\
\hline \multirow[t]{2}{*}{$1 ; 6$} & F1 & kiittä- & thanks & kiitti & a frozen past indicat SG3 \\
\hline & $\mathrm{F} 2$ & boppu(u) & \multicolumn{2}{|c|}{ 'the end $\sim$ ended $\sim$ ends' } & indicat $\mathrm{SG} 3$ \\
\hline
\end{tabular}


Early verb development of two finnish-speaking children:

a preliminary approach to miniparadigms

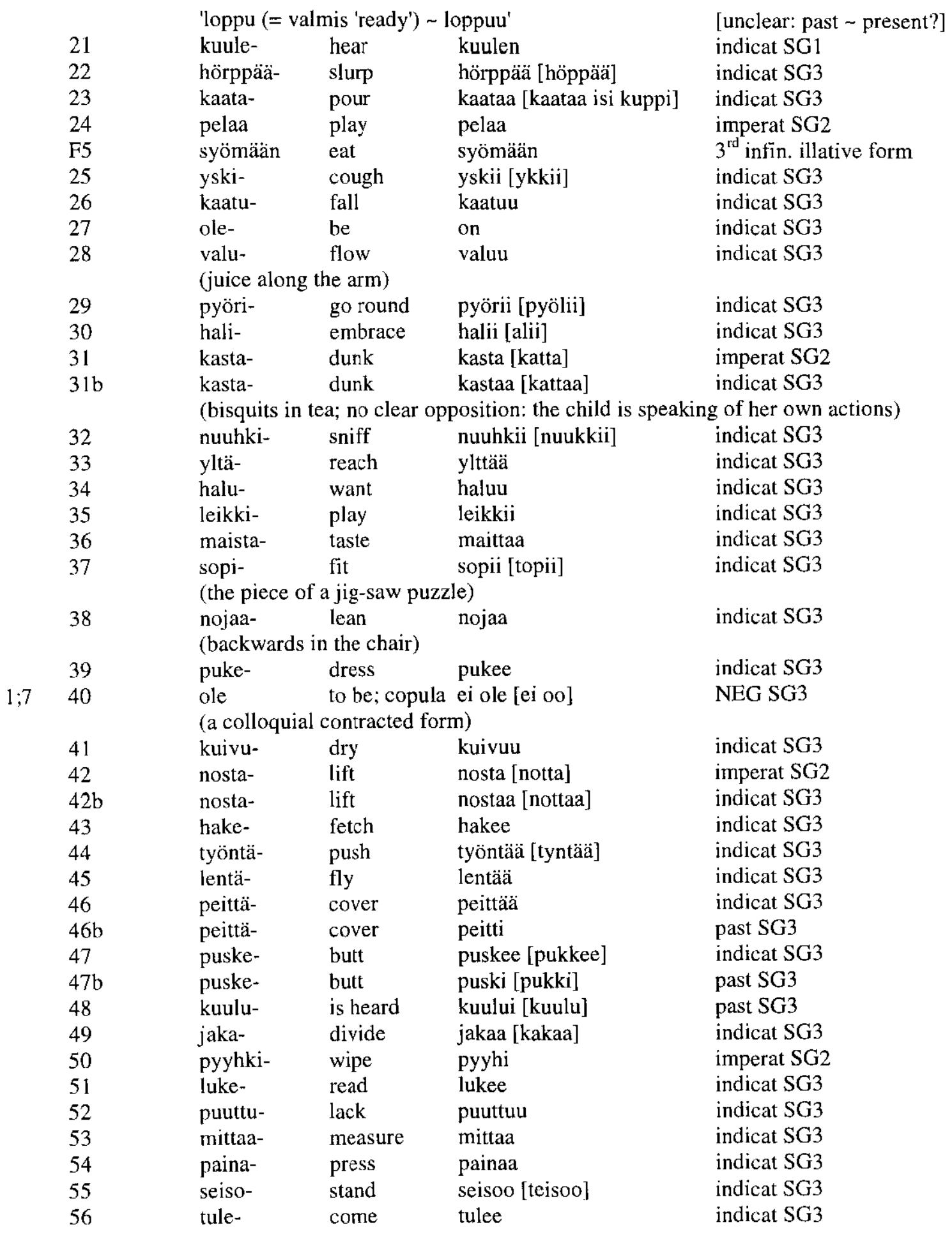

TABLE A2: The first $50+$ verbs of Tuomas [lemma $=($ strong $)$ vowel stem]

$\begin{array}{llllll}\text { AGE } & \text { NUMBER } & \text { LEMMA } & \text { ENGLISH } & \begin{array}{l}\text { first } \\ \text { occurrence }\end{array} & \text { CATEGORY } \\ 0 ; 8 & 1 & \text { anta- } & \text { give } & \text { anna! } & \text { imperat SG2 } \\ 0 ; 9 & 2 & \text { pelaa- } & \text { play } & \text { pelaa [peeaa] } & \text { imperat SG2 vs. indicat SG3 } \\ & 3 & \text { avaa } & \text { open } & \text { avaa } & \text { imperat SG2 vs. indicat SG3 }\end{array}$




\begin{tabular}{|c|c|c|c|c|c|}
\hline \multirow{3}{*}{$\begin{array}{l}1 ; 0 \\
1 ; 3\end{array}$} & 4 & e- & negation & $\mathrm{en}[\mathrm{em}]$ & NEG verb indic. SGl \\
\hline & 5 & kiikku- & swing & kiikkuu & indicat SG3 \\
\hline & 6 & nukku- & sleep & nukkuu [gukkuu, kukkuu] & indicat SG3 \\
\hline \multirow[t]{7}{*}{$1 ; 4$} & 7 & kaatu-/kaata- & fall & kaa & indicat SG3 \\
\hline & 8 & keikku- & swing & keckkuu & indicat SG3 \\
\hline & 9 & luke & read & lukee [ukee] & indicat SG3 \\
\hline & $4 b$ & $\mathrm{ei} / \mathrm{e}-$ & negation & ci ('empty') & NEG verb indic. SG3 \\
\hline & 10 & tippu- & fall & tippu(i) & past SG3 \\
\hline & & [1;4 pippu; $]$ & 6 pippu/tippu, & $1 ; 7$ tippu] & \\
\hline & $\mathrm{Fl}$ & loppu- & end & loppu [1;6 poppu] & past SG3 \\
\hline \multirow[t]{2}{*}{$1 ; 5$} & 11 & autta- & help & aula & imperal SG2 \\
\hline & 12 & tule- & come & tule $[\mathrm{tu}]$ & imperat SG2 \\
\hline \multirow[t]{6}{*}{$1 ; 6$} & 13 & kcikka- & swing, fall & keikkaa [kcekkaa] & indicat SG3 \\
\hline & 14 & kiipeä- & climb & kiipee [kippii] & indicat SG3 \\
\hline & 15 & piirtä- & draw & piirtää [piittää] & indicat SG3 \\
\hline & $10 \mathrm{~b}$ & tippu- & fall & tippuu [pippuu] & indicat SG3 \\
\hline & 16 & pyyhki- & wipe & pyyhkii [pyyhii, pyhhii] & indicat SG3 \\
\hline & 17 & työntä- & push & työntää [tyttää] & indicat SG3 \\
\hline $1 ; 6$ & 18 & pese- & wash & pestään [pettää] & passive \\
\hline \multirow{26}{*}{$1 ; 7$} & 19 & istu- & sit & istu [ittu] & imperat SG2 \\
\hline & 20 & katso- & look & kato & imperat SG2 \\
\hline & $18 \mathrm{~b}$ & pese- & wash & pestä [pettä] & $1^{\text {st }}$ infinitive \\
\hline & $18 \mathrm{c}$ & pese- & wash & pesty [petty] & pass II partis \\
\hline & 21 & hake- & fetch & hakee [akee] & indicat SG3 \\
\hline & 10 & autta- & help & auttaa [attaa] & indicat SG3 \\
\hline & 22 & heitlä- & throw & heittää [eittää] & indicat SG3 \\
\hline & 23 & hypрӓ- & jump & hyppää [yppää] & indicat SG3 \\
\hline & 19 & istu- & sit & istuu [ittuu] & indicat SG3 \\
\hline & 7 & kaata- & tilt over & kaataa & indicat SG3 \\
\hline & $24 a$ & kaatu- & fall & kaatuu [kaatuu, kattuu] & indicat SG3 \\
\hline & $24 b$ & kaatu- & fall & kaatui [kaatu, kattu] & past SG3 \\
\hline & 25 & kampaa- & comb & kampaa [kaapaa] & indicat SG3 \\
\hline & 26 & karkaa- & run away & karkaa [kaakaa] & indicat SG3 \\
\hline & 20 & katso- & look & katsoo [kattoo] & indicat SG3 \\
\hline & 27 & kävele- & walk & kävelee [käjee, kävee] & indicat SG3 \\
\hline & 28 & laske- & go down & laskee [lakkee] & indicat SG3 \\
\hline & 29 & lentä- & fly & lentää [nentää] & indicat SG3 \\
\hline & 30 & lähte- & go away & lähtec [lättee] & indicat SG3 \\
\hline & 31 & mahtu- & go in & mahtuu [mattuu] & indicat SG3 \\
\hline & 32 & mene- & go & menec & indicat SG3 \\
\hline & 33 & odotta- & wait & odottaa [oottaa] & indicat SG3 \\
\hline & 34 & paukku- & slam & paukkuu [pakkuu] & indical SG3 \\
\hline & 35 & pitä- & kcep & pitää & indicat SG3 \\
\hline & 36 & rikko- & break & rikkoo [ikkoo] & indicat SG3 \\
\hline & 37 & tiskaa- & $\begin{array}{l}\text { wash up } \\
\text { the dishes }\end{array}$ & tiskaa [tikkaa, tihkaa] & indicat SG3 \\
\hline \multirow[t]{16}{*}{$1 ; 8$} & $20 \mathrm{~b}$ & katso- & look & katsomaan [kattommaa] & $3^{\text {rd }}$ infinit. ILL \\
\hline & $6 b$ & nukku- & sleep & nukkumaan [ukkummaa] & $3^{\text {rd }}$ infinit. ILL \\
\hline & $32 b$ & mene- & go & mennään & passive \\
\hline & $18 \mathrm{a}$ & pese & wash & pestään [pehtää] & passive \\
\hline & $19 b$ & istu- & sit & istuttiin & passive past \\
\hline & $20 b$ & katso- & watch & katsottiin [katottii $]$ & passive past \\
\hline & 38 & haista- & smell & haistaa $[$ aittaa $]$ & indicat SG3 \\
\hline & 39 & haukku- & bark & haukkuu & indicat SG3 \\
\hline & 40 & huuta- & shout & huutaa [uutaa] & indicat SG3 \\
\hline & 41 & juokse- & run & juoksee $[$ uokkee $]$ & indicat SG3 \\
\hline & 42 & jäähty- & get cool(er) & jäähtyy [ähtyy] & indicat SG3 \\
\hline & 43 & kaiva- & dig & kaivaa & indicat SG3 \\
\hline & 44 & puha(lta)- & blow & puhalla $[p u h a]$ & imperat SG2 \\
\hline & 45 & kurkista- & peep, peek & kurkistaa [kukistaa] & indicat SG3 \\
\hline & 46 & kutitta- & tickle & kutittaa & indical SG3 \\
\hline & 47 & kylpe- & have a bath & kylpec [ky(y)pee] & indicat SG3 \\
\hline
\end{tabular}




\begin{tabular}{|c|c|c|c|c|}
\hline 48 & käänty- & turn (refl.) & kääntyy [käätyy] & indicat SG3 \\
\hline 49 & kääntä- & turn (trans.) & kääntää [käätääa] & indicat SG3 \\
\hline 50 & leikka- & cut & leikkaa [eikkaa] & indicat SG3 \\
\hline 51 & naura- & laugh & nauraa & indicat SG3 \\
\hline 52 & paina- & press & painaa & indicat SG3 \\
\hline 53 & pomppaa- & be bouncing & pomppaa & indicat SG3 \\
\hline 54 & potkaise- & kick & potkaisee $[p o k k a a]$ & indicat SG3 \\
\hline 55 & aja- & drive & ajoi $[a j i]$ & past SG3 \\
\hline $10 \mathrm{~b}$ & autta- & help & auttoi [autti] & past SG3 \\
\hline $22 \mathrm{~b}$ & heittä- & throw & heitti & past SG3 \\
\hline $30 \mathrm{~b}$ & lähte- & go away & lähti [ähti] & past SG3 \\
\hline $32 \mathrm{~b}$ & mene- & go & meni & past SG3 \\
\hline $7 \mathrm{~b}$ & kaatu- & fall & kaatui $[$ kaatu $]$ & past SG3 \\
\hline $48 \mathrm{~b}$ & käänty- & turn (refl.) & kääntyi [käänty] & past SG3 \\
\hline $23 b$ & hyppää- & jump & hyppäsi [hyppäs] & past SG3 \\
\hline 56 & irtoa- & come loose & irtosi [ittos] & past SG3 \\
\hline 57 & törmää- & bump & törmäsi [töömäs] & past SG3 \\
\hline
\end{tabular}

\section{Emergence of verb categories and the relations between verb forms}

\subsection{Two basic verb forms}

The imperative SG2 and the indicative SG3 forms are the first forms of verbs used by Finnish-speaking children. They can be regarded as basic forms of the verbs because they are morphologically basic (short and simple) and are used as building stones for more complicated forms to be acquired later. They are also basic from the categorial view: the $3^{\text {rd }}$ person sg. indicative is semantically the most neutral verb form and it has high frequency; the $2^{\text {nd }}$ person imperative can be regarded as a pragmatically basic verb form. These two forms are used accurately from the very beginning: the imperatives in requests and the indicatives in declarative sentences when speaking about ongoing action. At first, these two forms are typically not used from the same verb.

The imperative SG2 is formed by adding a final segment (realized phonetically as e.g. a glottal stop) to the vowel stem of the verb (if a consonant follows, this final segment is usually realized as a gemination of the consonant), but small children usually omit this final segment, e.g. istu, sano; syö, juo; kiipeä; tule, mene (cf. the verb groups in 1.2). The indicative SG3 is formed by lengthening the short stem-final vowel (the long final vowel remains unchanged), e.g. istuu, sanoo; syö, juo; kiipeää; tulee, menee.

The Finnish infinitives are used only later; they are morphologically more complex, formed by adding the suffix $-\mathrm{TA}\left(1^{\text {st }}\right.$ infinitive $),-\mathrm{TE}\left(2^{\text {nd }}\right.$ infinitive $)$ or $-\mathrm{mA}$ ( $3^{\text {rd }}$ infinitive $)$.

\subsection{Other verb forms}

The third verb form to be used by many Finnish-speaking children is the $3^{\text {rd }}$ person preterite (past tense). The very first preterite forms can be such as tippu 'fell' (when e.g. food or toys have fallen on the floor) or loppu 'end(ed)' (typically when the food has all been eaten up). Soon, different preterite forms are used accurately when speaking about actions and events that happened before the present time. There is a clear contrast between present and past, in some instances even in successive utterances, e.g. Tuulikki 1;8 äiti hakee 'the mother is fetching (a book) vs. äiti haki 'the mother fetched' (when the mother had brought the book).

Also the negation construction emerges rather early, but it is first used mostly in truncated form (only the negation verb). 
The early occurrences of other verb forms are mostly isolated and rare but used in a correct way, for example Tuulikki 1;4 the passive present form mennään 'let's go', 1;6 the $3^{\text {rd }}$ infinitive illative syömään 'come to eat'; Tuomas 1;6 the passive present form pestään 'let's wash', 1;7 the $1^{\text {s1 }}$ infinitive pestä 'to wash' and the passive past participle pesty 'has been washed'.

\subsection{Order of emergence of the inflectional categories}

Both Tuulikki and Tuomas had the same order of emergence

a) between different categories

person $+\operatorname{mood}(=$ imperat. SG2 + indicat. SG3) $>$ tense $>$ voice/number (although some passive forms were used early in the function of PL1 as is usual in colloquial Finnish)

b) subcategories within categories

person (indicative): SG3 (but in imperative SG2 first) > SG1 > SG2 > PL2/3 (PL1 = passive!)

person (imperative): $\mathrm{SG} 2>$ (passive in the function of PL1) $>$ PL2 $>3^{\text {rd }}$

person (indicative + imperative): $\mathrm{SG} 2+3>$ (passive in the function of $\mathrm{PL} 1$ ) $>\mathrm{SG} 1>\mathrm{SG} 2>$ PL2 > PL3 (usually replaced by SG3 in spoken Finnish)

tense: present $>$ preterite

voice: active $>$ passive

Cf. the acquisition order of the verb suffixes of 25 Finnish-speaking children (based on the order of the median child, Toivainen 1980): basic forms $>$ past tense $>$ negation (analytic) $>$ SGI $>$ passive $>$ perfect $>3^{\text {rd }}$ infinitive illative $>1^{\text {st }}$ infinitive $>$ past negation (analytic) $>$ $\mathrm{SG} 2$ indicative $>$ conditional $>2^{\text {nd }}$ infinitive inessive.

\section{Emergence of miniparadigms}

The miniparadigms are established following the criteria of Kilani-Schoch and Dressler (2000): spontaneous production, articulatory accuracy in the suffix elements, contrasting contexts, recurrence. Only one imitated form is taken into consideration: the truncated passive laite (< laitetaan 'let us put') in the recording 1;7:28 of Tuulikki.

\subsection{The first contrasting verb-forms of Tuulikki}

The first oppositions of verb forms to emerge in Tuulikki's speech were oppositions of the two basic verb forms, the imperative SG2 and the indicative SG3:

$\begin{array}{lll}\text { Tuulikki } & \text { 1;5 ota 'take!' } & \text { : ottaa 'takes' (diary data) } \\ 1 ; 7 \text { nosta 'lift!' } & \text { : nostaa 'lifts' (diary data) } \\ 1 ; 7 \text { katso [kato] 'look!' } & \text { : katsoo [kattoo] 'is looking' } \\ 1 ; 8 \text { katso [kato] 'look!' } & \text { : katsoo [kattoo] 'is looking' } \\ 1 ; 8 \text { ota 'take!' } & \text { : ottaa 'takes' } \\ 1 ; 8 \text { tule } ~ \text { tuu 'come!' } & \text { : tulee 'is coming' (diary data) }\end{array}$

In the contracted verbs (e.g. Tuulikki 1;3 avaa, 1;5 pakkaa, 1;6 hörppää, pelaa, nojaa) there is no morphological difference between the two basic forms before the children start to use the final segment (gemination glottal stop) of the imperative (then: indicative - VV vs. imperative $\left.-V V^{\prime}\right)$; the inflectional category of the occurrences can yet be inferred from the context. 
Soon the following oppositions of verb forms emerged, namely those consisting of indicative SG3 present and preterite:

Tuulikki (1;6 [unclear:] loppu ['ready; end(ed)] : loppu(u) [length of the vowel unclear])

1;7 heittää : heitti'throws : threw' (record.)

1;7 kaatuu : kaatu

'is falling : fell' (record.)

1;7 nukkuu : nukku

'is sleeping : slept' (record.)

$1 ; 7$ on : oli

'is : was' (diary data)

$1 ; 7$ peittää : peitti

'covers : covered' (diary data)

$1 ; 7$ puskee : puski

'butts : butted' (diary data)

$1 ; 7$ vie : vei

'takes away : took away' (diary data)

$1 ; 8$ antaa : anto

$1 ; 8$ hakee : haki

'gives : gave' (diary data)

$1 ; 8$ keittää : keitti

'fetches : fetched' (diary data)

$1 ; 8$ kerää : *keri (= keräsi)

'is cooking : cooked' (diary data)

$1 ; 8$ laittaa : laitto

'is collecting : collected' (diary data)

$1 ; 8$ loppuu : loppu

'puts : put' (diary data)

$1 ; 8$ lähtee : lähti

$1 ; 8$ menee : meni'

$1 ; 8$ nukkuu : nukku

$1 ; 8$ on : oli

$1 ; 8$ ottaa : otti

$1 ; 8$ pitää : piti

'ends : ended' (diary data)

'goes away : went away' (diary data)

'goes : went' (diary data)

'is sleeping : slept' (diary data)

'is : was' (diary data)

'takes : took' (diary data)

'holds : holded' (diary data)

$1 ; 8$ putoo : puto $\sim$ putos

'is falling : fell' (diary data)

$1 ; 8$ saa : sai

$1 ; 8$ sanoo : sano

$1 ; 8$ syö : söi $\sim *^{*}$ syöi

$1 ; 8$ syöttää : syötti

$1 ; 8$ tulee : tuli

'gets : got' (diary data)

'says : said' (diary data)

'is eating : ate' (diary data)

'feeds : feeded' (diary data)

$1 ; 8$ vaihtaa : vaihto

'is coming : came' (diary data)

$1 ; 8$ vetää : veti

'changes : changed' (diary data) [-ht- > -tt-]

'pulls : pulled' (diary data)

$1 ; 8$ vie : *viei (= vei)

'takes away : took away' (diary data)

There were also some early occurrences of negation form, $1^{\text {st }}$ person singular form and the illative of the $3^{\text {rd }}$ infinitive. The same verb was always used also in the indicative SG3 form.

The first negation forms were used by Tuulikki in the verb meaning 'to be, to exist' (infinitive olla) at the age of 1;7: on 'is' : ei oo 'is not' (colloquial variant of the negation, Standard Finnish ei ole), diary notes also from the age of $1 ; 8$. Together with the preterite these two forms established a three-member suppletive paradigm on 'is' : oli 'was' : ei oo 'is not'. At the age of 1;8 negation occurred at least in the following oppositions: autti 'helped' (a form based on analogy, regular form auttoi 'helped') vs. ei isi auta 'the father shall not help' (negation used in a modal context) and putoo 'is falling' : ei pulo 'does/did not fall' (truncated form of the main verb).

At the age of 1;8 Tuulikki used two variants of her playful ultimatum: muuten suutun muuten suuttuu 'otherwise I will get angry otherwise gets angry'. This seems to be a first candidate to the opposition of SG1 and SG3 indicative.

The verb nukkua 'to sleep' was used by Tuulikki frequently in the $3^{\text {rd }}$ person indicative form. At the age of $1 ; 8$ she also tried to use the illative of the $3^{\text {rd }}$ infinitive $(n u k k u+m a+a n)$, but because of the trochaic tendency she shortened the form: ei vielä nukku 'not yet sleep-', ihan vielä nukku 'quite yet sleep-' and pankkii nukkuu 'on the balcony to sleep' (the last form seems to represent the colloquial variant of the illative of the $3^{\text {rd }}$ infinitive, $n u k k u+u n$, where the $m a$ - 
suffix of the $3^{\text {rd }}$ infinitive is dropped). At this age Tuulikki also used the colloquial preterite $n u k k u$ but in the diary data there is unfortunately only one occurrence of this form.

\subsection{The first true miniparadigms of Tuulikki (with at least three members)}

At the age of 1;7 Tuulikki started to use three-member miniparadigms. One of them was suppletive: Tuulikki used from the verb olla 'to be, to exist' the $3^{\text {rd }}$ person indicative on 'is', the colloquial variant of the negation form ei oo 'is not' and the preterite oli 'was'.

Another candidate for a three-member miniparadigm at the age of 1;7 was the verb laittaa 'to put'. From this verb, Tuulikki used the $3^{\text {rd }}$ person indicative laittaa 'puts', the analogical preterite laitti [= laittoi] 'put' and (in an answer to a question, recorded session 1;7:28) the shortened passive form laite [= laitetaan] 'let's put'; here the passive suffix itself is dropped but the passive is nevertheless signalled by the change of the final stem vowel from $a$ to $e$ (laita->laite). The trochaic phase of Tuulikki explains why the trisyllabic laitetaan 'let's put' was shortened; yet, laite was used as an adequate answer to the question "laitetaanko ...?" (= shall we put...?).

The first three-member miniparadigms thus emerged soon after Tuulikki had more than 50 verb forms.

At the age of 1;8 Tuulikki had several three-member miniparadigms. One type of the miniparadigms consisted from the three early verb forms: imperative SG2, present indicative SG3 and preterite SG3. These forms were frequently used from the following verbs: anna 'give' : antaa 'is giving' : anto(i) 'gave' and tule tu(u) 'come!' : tulee 'is coming' : tuli 'came'.

These two paradigms are rather transparent, although in the first one there are certain stem alternations: grade alternation (nt : $\mathrm{nn}$ ) and the alternation $\mathrm{a} \sim \mathrm{o}$ in the final stem vowel. From the second verb, also the passive preterite was used: tultiin 'we came'. The passive is based on the consonant stem, which makes it less transparent.

Another type of miniparadigms consisted of active SG3 (present and preterite, both frequently registered) and passive in the function of PL1 (the passive present mennään was attested already at the age of $1 ; 4$, now also passive preterite and negation): menee 'goes' : meni 'went' : mennään 'let's go' : mentiin 'we went' : ei mennä 'we shall not go'. Tuulikki used also the SG2 imperative from this verb, but there is only one occurrence in the diary data. The paradigm is rather transparent, although the passive forms are based on the consonant stem.

A third type was the suppletive paradigm of the verb olla 'to be, to exist': Tuulikki used the $3^{\text {rd }}$ person indicative on 'is', the colloquial variant of the negation form ei oo 'is not' and the preterite oli 'was'. The corresponding forms were also used from the verb ottaa 'to take', but the negation form ei ota 'does not take' was used only during the last day of the age month $1 ; 8$ and only in the context of eating. These forms (SG3 present and preterite + negation) were furthermore used from the verb saada 'to get; may', but the negation form belonged to the modal use of this verb ( $e$ i saa 'must not') and the two other forms to the meaning 'to get' (SG3 present $s a a$ 'gets' and preterite $s a i$ 'got'). One further candidate to this group of miniparadigms is pudota 'to fall' with the forms putoo 'is falling', ei pulo 'does/did not fall' : puto (s) 'fell', but the forms of this contracted verb were both truncated and influenced by analogy (cf. 7.1). These are perhaps not true miniparadigms but nevertheless they show that the SG3 negation form is getting productive.

Within the first miniparadigms, one special case was the verb syöd $\ddot{a}$ 'to eat'. At the age of 1;8

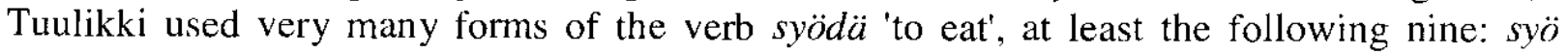
(present indicative SG3) 'is eating', syö! (imperative SG2), söi syöi (preterite, both regular and analogical) 'ate', syömään (illative of the $3^{\text {rd }}$ infinitive) 'go eating', syödään (the present 
tense of the so-called "passive") 'let's eat', syötiin (preterite of passive) 'was eaten', syönyt (past participle of active, e.g. syönyp paljon 'has eaten much) 'has eaten', syöty (past participle of passive, e.g. syöty kaikki 'all has been eaten up') 'has been eaten', syödä [tyälä] (1 ${ }^{\text {st }}$ infinitive, e.g. tyälä puuvoo 'to eat porridge'). Some of these nine forms have been registered only once or twice, but the following ones were used frequently and were registered at least three times: syö, söi syöi (both variants), and syödään (passive in the function of PL1).

In sum: at the age of 1;8 Tuulikki had at least the following true miniparadigms:

1. anna 'give' : antaa 'is giving' : anto(i) 'gave'

2. tule $\sim t u(u)$ 'come!' : tulee 'is coming' : tuli 'came'

3. menee 'goes' : meni 'went' : mennään 'let's go' : mentïn 'we went' : ei mennä 'we shall not go'

4. on 'is' : ei oo 'is not' (colloquial) : oli 'was'

5. syö 'is eating' : söi syöi (both variants) 'ate' : syödään (passive in the function of PL1)

Further candidates for three-member miniparadigms at the age of 1;8 are saada (both modal use and the meaning 'to get') and pudota 'to fall'.

The recordings $1 ; 9$ and $1 ; 10$ are only partly transcribed; both of the short transcripts include a few three-member miniparadigms, e.g. 1;9:16 on 'is' : oli 'was' : ollaan 'we are' (passive in the function of PL1), 1;10:11 tulee 'comes' : tule! 'come!' : tullaan 'we are coming' (= passive in the function of PL1), syö 'is eating' : syömään 'come to eat' : syödään 'let's eat' (= passive in the function of PL1). The recording 1;11 is the next one to be transcribed; unfortunately, there is no recording from the age of $2 ; 0$. In the transcript $2 ; 1$ there are several miniparadigms of even 4 and more members: halua3, nukku3, syö3, mene4, pane4, saa4, luke5, ole7.

The number of the first true miniparadigms (with at least three members) in Tuulikki's corpus were:

$$
\begin{array}{ll}
1 ; 7 & 1+1 \text { (cf. 6.2.) } \\
1 ; 8 & 4+2 \text { (cf. 6.2.) }
\end{array}
$$

\subsection{The first contrasting verb-forms of Tuomas}

The first verb of Tuomas occurring both in the present tense and in the preterite was 1;4 (and onwards) tippu 'fell down' vs. 1;6 tippuu 'is falling down' (when porridge was continuously falling from the spoon on the tablecloth). Interestingly enough, the past tense form of this verb emerged first. In other verbs the present tense emerged first:

\section{1;7 kaatuu 'is falling' : kaatu 'fell' and} 1;8 auttaa 'helps' : autti 'helped'

Another early contrast was the opposition of imperative SG2 and indicative SG3, e.g. 1;7 kato(kursiviert) 'look!' vs. kattoo(kursiviert) 'is looking'.

On the basis of diary data, the first miniparadigm of Tuomas was 1;7 kato(kursiv.) 'look!' : kattoo(kurs.) 'is looking' : katottiin(kurs.) 'was looked' (passive preterite) : kattomaan(kurs.) 'to look' (illative of the 3rd infinitive). Another candidate for an early three-member miniparadigm consisted of exceptional forms: 1;7 pestään 'let's wash' : pestä 'to wash' : pesty 'has been washed'. Yet these forms were rote-learned and used only in connection with the washig routines. Moreover, the passive past participle pesty was the only representant of this inflectional category and should thus not be counted as such an inflectional form that could be a member of a paradigm in this phase. 


\subsection{Miniparadigms and the emergence of categories}

In the first true miniparadigms of Tuulikki the form categories that occurred were the same that also in general emerged early: imperative SG2, indicative SG3 present and preterite, passive and the SG3 negation form. The most important morphological contrasts in the first true miniparadigms were the following ones:

imperat. SG2 vs. indicat. SG3, e.g.

anna : antaa ('give' : 'gives')

indicat. SG3 present vs. preterite, e.g. tule : tulee ('come' : 'comes')

on : oli ('is' : 'was') antaa : anto(i) ('gives' : 'gave')

tulee : tuli ('comes' : 'came') menee : meni ('goes' : 'went')

active SG3 vs. passive (in the function of PL1), e.g. menee : mennään ('goes' : 'let's go') syö : syödü̈̈n ('eats' : 'we are eating') on : ollaan ('is' : 'we are') indicat. SG3 affirmative vs. negative, e.g. on : ei ole ei oo ('is' : 'is not')

The above analysis of the first miniparadigms of Tuulikki is based both on recordings and diary data. There is not as much diary data from the speech of Tuomas, and from his recordings only 1;6 and 1;7 have been transcribed, so thus far only the first contrasts can be presented:

imperat. SG2 vs. indicat. SG3, e.g.

indicat. SG3 present vs. preterite, e.g. kato : kattoo ('look!' : 'is looking at')

tippuи : tippu(i) ('is falling down' : 'fell down')

active SG3 vs. passive (in the function of PL1), e.g. menee : mennään ('goes' : 'let's go')

finite verb forms vs. 3 rd infinitive illative, e.g.

nukkuu : nukkumaan ('is sleeping' : 'to sleep')

\section{Analogical formations}

\subsection{The formation of the preterite (past tense)}

There is only one past tense (preterite) suffix in Finnish, namely $i$. Yet there are three productive preterite types in Standard Finnish: those ending in -i, -si and -oi. In colloquial Finnish there is a fourth type: the labial final vowel of the SG3 present is shortened in preterite, e.g. loppuи 'ends' : loppu 'ended', sanoo 'says' : sano 'said'. The si-preterite is typical for contracted verbs (cf. 1.2.3).

The first types to emerge in child language are besides the colloquial one especially the i-type and the si-type. These two productive types also often expand beyond the limits of their normal use. The child usually starts from either the i- or the si-preterites but later, when the child acquires other preterite types, also they may expand beyond their normal use; this holds in some degree also to the oi-type.

As many other Finnish-speaking children, Tuulikki started from colloquial vowel shortening (tippu 'fell' vs. tippuu 'is falling') and the i-type; she used analogical variants with the latter one from the age of 1;8 on especially in contracted verbs and one-syllabic verbs:

$1 ; 5$ tippu

1;6 poppu 'loppu' (BUT: this type cannot expand beyond the verb group ending in labial vowel)

1;7 peitti, puski, heitti 
$1 ; 7$ söi, vei

1;7(end) SELF-CORRECTION: lunta sati/sato

1;8 ANALOGICAL FORMS: kerää : keri (pro keräsi 'collected'; the anal. model is constituted by such verbs as heittää : heitti, syöttää : syötti, pitää : piti etc. - cf. 6.1), putoo : puto : ei pulo (pro putoo putoaa 'is falling', putosi 'fell', ei putoa/pudonnut 'does/did not fall; the anal. model is sanoo : sano : ei sano, nukkuu : nukku : ei nuku etc.), syöi, viei (pro söi, vei, cf. the forms in 1;7 above)

1;9 ANALOGICAL FORMS: kiipee : kiipi (pro kiipesi 'climbed')

1;10 ANALOGICAL FORMS: harjaa: harjo (pro harjasi 'brushed')

Tuulikki also used the i-type instead of the oi-type, e.g. laittaa : laitti (pro laittoi 'put'). The inclination to replace the relatively rare oi-type (e.g. laittaa : laittoi) by the i-type (laittaa: laitti) where the $i$-suffix causes the deletion of the stem-final vowel, is a common phenomenon both in child language and in certain spoken variants of Finnish (e.g. many dialects).

At the age of 1;11 Tuulikki started to use s(i)-preterites, e.g. putos (< putosi) 'fell down', pelkäs (< pelkäsi) 'was afraid of', tykkäs (< tykkäsin) 'liked', halus (< halusi) 'wanted'. This new preterite type expanded to other verbs than contracted ones, e.g. 1;11 hakes 'fetched' (pro haki, SG3 present tense hakee), lennäs 'flew' (pro lensi, stem of the present lentä- lennä-), 2;0 auttasin 'I helped' (pro autoin, stem of the present autta-), hakes, nauras 'laughed' (pro nauroi). This analogical expansion was soon weakened, but interestingly enough, in one group of verbs it not only remained but even got stronger: in the i-stems, in which the opposition of present and preterite has no overt marking in the $1^{\text {st }}$ and $2^{\text {nd }}$ person in Standard Finnish (e.g. leikin 'I play', leikin 'I played'). Here the analogical expansion of the si-preterite gives the possibility to mark the preterite forms with the si-element. This possibility was utilized by Tuulikki, e.g. 2;3 leikkisin 'I played', poimisin 'I picked up' (Standard Finnish poimin).

Similar expansion of the si-preterite also appears in certain spoken variants of Finnish (e.g. in the SW dialects).

In the same way as Tuulikki, also Tuomas started from the i-type and expanded it to certain oi-preterites, e.g. 1;8 ajaa : aji (pro ajoi 'drove') and auttaa : autti (pro auttoi 'helped'). A little later, Tuomas began to use the $s$-type in contracted verbs (1;9 avas 'opened', piippas 'peeped', toppas 'stopped') and favoured it in expence of other types, both in expence of the oi-type (1;9 auttas pro auttoi 'helped', laittas pro laittoi 'put'), and in expence of the i-type (1;9 ylttäs pro yltti 'reached' and itkes pro itki 'cried').

In the class of one-syllabic verbs, the normal preterite is formed by diphthong change (present syö 'is eating' : preterite sö i 'ate', present vie : preterite vei etc.) or the formation of a diphthong from a long vowel (e.g. saa 'gets' : sai 'got'). These regular preterites usually emerge first in child language (e.g. Tuulikki 1;7 söi, vei), but later on many Finnish-speaking children produce more transparent (= without changes in the stem) preterite forms like $s y \ddot{o}+i$ 'söi', vie $+i$ 'vei' despite of their articulatory difficulties (triphthongs instead of diphthongs), e.g. Tuulikki $1 ; 8$ syöi, viei. These analogical forms witness that the child is actively processing morphological elements.

\subsection{Other early types of analogies}

Typical early analogies in verb inflection are the expansion of the alternation between short final vowel in imperative SG2 and long final vowel in indicative SG3 to verbs which don't have this alternation in the standard language. One possible type of analogy is the shortening 
of the final long vowel in the contracted verbs, e.g. Tuulikki 1;10 imperative SG2 leika (cut! pro leikkaa, cf. the indicative SG3 leikkaa), 1;11 negat. imperative SG2 älä napa (don't take! pro nappaa, cf. the indicative SG3 nappaa).

\section{Conclusions}

The productive morphological processing of verbs seems to begin with the formation of past tense forms; they are clearly contrasting with present tense forms of the same verbs. The earlier two-member miniparadigms of imperatives and indicatives may also at least partly be based on morphological processing, but they may consist of two separate rote-learned forms as well.

\subsection{The protomorphological period and the demarcation of the phases}

\subsubsection{Onset of protomorphology}

- first analogical forms: isolated analogies at Tuulikki 1;7, more systematic at the age of 1;8

- no clear verb spurt but a relatively steady increase of verb forms (this line of development might be at least partially due to the use of diary data)

\subsubsection{Syntactic development: some preliminary observations}

The one-word stage of Tuulikki continued till the age of 1;5. At the age of 1;5 Tuulikki used mostly 1 - and 2-word utterances but at the end of 1;5 she produced some isolated 3-word utterances, e.g. kukka kakka mane < sukka jalkaan pane 'put the sock in the foot [illative]'. It seems that she had no clear 2-word stage.

At the age of 1;6 Tuulikki combined the subject and the predicate verb with an adverbial (e.g. talo tähän topii [= sopii] 'house here [illative] fits', when playing a jigsaw puzzle) but the case marking of the adverbial was sometimes defective: kaataa, isi, kuppi 'pour father cup' (the father is pouring tea in the cup; no illative suffix).

At the age of 1;7 suffix elements were still dropped in longer utterances, e.g. in Puppe nuukkii [= nuuhkii] kissa [= kissaa] 'Puppe [= a dog] sniffs the cat' (no object marking) and hakee Tuuti Leego pali [= palikan] 'fetches Tuuti [= Tuulikki] the Lego brick' (last word truncated). In both sentences there is no morphological marking of the object but both the subject and the object are well specified by the word order.

At the age of 1;8 Tuulikki used already quite clear 4-word utterances, e.g. vesimuki(n) mukaan tarttee Tuuti 'the water mug along needs Tuuti', kantaa Tuuti hatun tinne [= sinne] 'carries Tuuti the hat over there'.

\subsection{Observations about the input-dependence}

Certain long ( $=$ target forms have more than two syllables) forms seem to be input-dependent at least to some extent, e.g. the passive form laite(taan) 'we shall put' was produced as an adequate answer to the question laitetaanko? 'shall we put?'. 


\subsection{Language-specific features}

\subsubsection{Homophony/syncretism}

In verbs of the first group (cf. 1.2.1) with a final A: the $1^{\text {st }}$ infinitive is identical with the indicative present SG3 in early child language, when the final gemination $\sim$ glottal stop of the infinitive is not yet used. In verbs of the groups 2 and 3 (cf. 1.2.2 - 1.2.3) the indicative SG3 is identical with the imperative SG2 in early child language, when the final gemination glottal stop of the imperative is not yet used.

\subsubsection{Non-inflected vs, inflected forms}

The basic forms have very little if any morphological marking (depending on the verb class, cf. 1.2) and they are often used before other verb forms. Nevertheless, from certain verbs other forms are used first, e.g. (rote-learned) passives, infinitives and participles.

\subsubsection{Nouns vs. verbs}

Active morphological processing of nouns typically starts from the formation of genitiveaccusatives which clearly constrast with nominatives. Active morphological processing of verbs often starts from the formation of past tense at about the same age. Even more striking is the observation that the active production of A-partitives often starts in the same time as the production of A-infinitives.

The order of acquisition of verb vs. noun suffixes: verb suffixes are marked with bold letters in the following list which is based on the recorded material of 25 Finnish-speaking children aged $1-3$ years. The serial order of the suffixes is defined by the age of the median child (Toivainen 1980: $33,44,160-163$ ): basic forms of verbs (= imperat $2^{\text {nd }}$ or indicat $3^{\text {rd }}$ ), partitive, past tense (preterite), negat. construction, adessive (adv.), illative, inessive + allative (adv.), $\mathbf{1}^{\text {st }}$ person singular, adessive, plural -i-, genitive (attr.), passive, inessive, accusative, allative, perfect $3^{\text {rd }}$ singular, $3^{\text {rd }}$ inf. illative, plural $-t$, genitive $+P P$, elative $(\operatorname{adv}),. \mathbf{1}^{\text {st }}$ infinitive, preterite negative, illative + ablative (adv.), $2^{\text {nd }}$ person singular, elative, perfect not $3^{\text {rd }}$, conditional, ablative, $2^{\text {nd }}$ infinitive inessive, ablative.

\subsubsection{Synthetic vs. analytic}

Synthetic inflection precedes analytic: the long analytic constructions are first shortened to their key parts, e.g. the negat. construction is realized by the negation verb only or the compound past is realized by the participle of the main verb only.

\subsubsection{Competition between early verb and noun expressions}

The dynamic local cases, especially illative, seem to be an alternative to certain verb forms in early child speech (c.f. kotiin and syliin in 3.c above). Pragmatically they are very near such passive forms as mennään 'let's go' or syömään 'come and eat', and they have also the same type of suffixes $=$ vowel lengthening $+n$.

\subsubsection{Causatives}

Among the verbal suffix elements the first derivational element to be used productively (in the own neologisms of the child) was the causative suffix -TTA-. Tuulikki used this suffix eagerly, e.g. at the age of 2;0 she produced the following own causative derivatives:

nouseta! ( = nouse+TTA+IMPERAT.SG2 = rise+CAUSAT+IMPERAT.SG2 'lift!') 
juoksettaa (= juokse+TTA+INDICAT.SG3 = run+CAUSAT+INDICAT.SG3 'make run') kaadutan (= kaatua+TTA+INDICAT.SG1 = fall+CAUSAT+INDICAT.SG1 'I make fall down')

Tuomas had at the same age $(2 ; 1-2 ; 3)$ only one own word formed with a causative derivative element:

hypätä! (= hyppää+TTA+IMPERAT.SG2 = jump+CAUSAT+IMPERAT.SG2 'make to jump'); he used this when he wanted to be lifted as if he would make a big jump.

\subsection{Typological considerations}

The morphological system of Finnish is relatively rich; the early emergence of miniparadigms is expected.

Iconicity of the basic forms of the Finnish verbs: the early imperatives of the $2^{\text {nd }}$ person singular end in a short vowel, which iconically reflects the limits of the scope of action (e.g. anna 'give' when the child wishes something to be given to her). In contrast, the $3^{\text {rd }}$ person indicatives end in a long vowel, which iconically reflects the ongoing action that continues; the $3^{\text {rd }}$ person indicatives could most often be accurately translated with the English ing-form, e.g. nukkuu 'is sleeping'.

\section{References}

Toivainen, Jorma (1980): Inflectional affixes used by Finnish-speaking children aged $1-3$ years. Suomalaisen Kirjallisuuden Seura (The Finnish Literature Society), Helsinki. 